\title{
Strategy Building through Keeping English Learning Journals
}

\author{
Pei-Ling Yang ${ }^{1, *}$ \\ ${ }^{1}$ Center for General Education, Oriental Institute of Technology, Taiwan \\ *Correspondence: Center for General Education, Oriental Institute of Technology, Taiwan. E-mail: \\ peiling1225@hotmail.com
}

Received: September 25, 2018 Accepted: October 10, 2018 Online Published: December 11, 2018

doi:10.5430/ijelt.v6n1p14 URL: https://doi.org/10.5430/ijelt.v6n1p14

\begin{abstract}
The present study aims to investigate the effect of English learning journal on strategy building. Learning strategies are proved and claimed by many researchers that it has a close association with good language learners. However, there is little research on building learning strategies through keeping a weekly journal. The participants, in the study, were 33 EFL Taiwan college students, taking English for Socializing as an optional course for one semester. During the semester, they were required to keep a weekly learning journal related to their English learning (in-class and after class) and to send it to the instructor-researcher via the Moodle. The Moodle, in the study, serves as the function of diaries, providing an instant and convenient way of sending and saving information. The study's instrument, Oxford's Strategy Inventory of Language Learning (SILL), is applied to examine whether or not there is any significant difference of the learners' strategy use before and after the study. For the purpose of finding out whether or not there are significant differences in the numbers of employing language learning strategies, a series of quantitative tests are carried out. Besides the quantitative results of SILL, a semi-structured post-interview is also administered to unfold more about the English learning journal and strategy use from the perspectives of the learners. The findings of the study could shed light on language learning, especially on strategy building.
\end{abstract}

Keywords: language learning strategies, journal writing, EFL learners

\section{Introduction}

The focus of language education has been shifted from more teacher-dominated to more interactive and communicative (Tarone \& Yule, 1989). Language learners now should be encouraged to be more autonomous in their learning and be more self-directed in the process of language development (Cohen, 1998). Due to the test-oriented learning environment in Taiwan, the learners are used to passive learning and rote memorization. Learners, however, could be promoted to be more responsible for their own learning through effective activities. Journal writing is one of the activities, which makes learners to reflect on the process of learning and to take more control of their learning. Therefore, in the present study, the purpose is to investigate the effect of English learning journal on strategy building.

\section{Literature Review}

Learning strategies are defined by Cohen (1990, P.5) as "learning processes which are consciously selected by the learner. The element of choice is important here because this is what gives a strategy its special character. These are also moves which the learner is at least partially aware of, even if full attention is not being given to them." In short, learning strategies are not naturally acquired by learners but something they learn and use for the purpose of enhancing their learning performance (Cohen, 1998). Language strategies, in other words, provided learners with opportunities to participate actively in authentic communication, which also encourages the development of communicative competence (Oxford, 1990). Language learning strategies, according to Oxford (1990), can be classified into two categories: direct and indirect strategies. Direct strategies include memory, cognitive, compensation strategies while indirect, metacognitive, affective, and social strategies.

Many studies investigating the relationship between learning strategies and language performance and have found out that proficient learners apply more strategies than less proficient ones (Bremner, 1999; Green \& Oxford, 1995; 
Lai, 2009; Norton \& Toohey, 2001; Shih, Chern, \& Reynolds, 2018; Vann \& Abraham, 1990; Yilmaz, 2010; Zhang, 2010). Less successful language learners, moreover, are less flexible and less effective in the way of using strategies and applying them to learning (Vann \& Abraham, 1990). Ellis (1985), in a similar vein, suggested that learning strategies be one of the essential processes for language development. Learning strategies, learners' characteristics, and situational variables have interacted with each other, which could yield a significant influence on language development, claimed by Gardner and MacIntyre (1993).

Besides the advantages provided by language learning strategies in language development, journal-keeping is also claimed to be beneficial to language learning. Through journal-keeping, learners would be more aware of their learning processes and be more able to recognize their learning problems. In other words, keeping a journal is a self-discovery and self-evaluation process, leading learners to a world of better language performance. However, there is little research investigating the effect of English learning journal on strategy building, especially for EFL non-English-majored college learners. Therefore, in the present study, three research questions are raised as follows.

1. What is the most frequently-used language learning strategy used by the non-English-majored college learners?

2. What is the least frequently-used language learning strategy used by the non-English-majored college learners?

3. Is there any difference in the number of language learning strategies after the journal writing activity?

\section{Method}

As stated in the previous part, the purpose of the study is to investigate the effect of English learning journal on strategy building. This method section is divided into four parts: descriptions of participants, the instruments, data collection procedures, and data analysis.

\subsection{Participants}

The participants, in the present study, were 33 female college students in northern Taiwan, taking English for Socializing as an optional course for one semester. All the participants majored in Nursing but they reported to be interested in English learning. Based on the instructor-researcher's observation, the majority of them were able to and willing to speak out English. The whole instruction, therefore, was conducted in English.

\subsection{Description of the Setting and the Instruments}

The class instruction was in a face-to-face classroom; however, the participants were asked to write English journals after class. The English journal was sent to the instructor-researcher via the Moodle. The Moodle, in the study, serves as the function of diaries, providing an instant and convenient way of sending and saving information. The participants and the instructor all at least had three years of experiences using the Moodle as an academic platform for more teacher-student interaction. Before and after they wrote the English journal, they were asked to complete Oxford's Strategy Inventory of Language Learning (SILL, version 7.0), a self-reported 5-scale Likert-type questionnaire. The SILL consists of six strategy type: memory, cognitive, compensation, metacognitive, affective, and social strategies. Many researchers have claimed the high validity and reliability the SILL. The SILL, in the present study, was translated into Chinese and tested for its reliability and validity.

\subsection{Data Collection Procedures}

During the semester, they were required to keep a weekly learning journal for eight times. The content of the journal could be related to their English learning (in-class and after class) or their daily life. Before and after the semester, the students were asked to fill in the SILL. The time for completing the SILL lasted twenty five to thirty minutes. While the students were filling out the questionnaire, the instructor was also in the presence of the class, guiding tm to answer the questions and elaborating the meaning of the questions.

\subsection{Data Analysis}

The data of the SILL, after the semester, were collected and analyzed through descriptive and referential statistics. Referential statistics used in the study was paired-samples t-test in order to investigate whether or not there were any differences of the students' strategy use after they worked on the journal writing activities. In addition to the quantitative results, qualitative findings were gathered from the open-ended questions and systematically categorized in support of the SILL findings.

\subsection{Ethical Considerations}

All the participants were informed of the study purpose and of the possibility to withdraw from the study under any circumstance. The confidentiality of the participants was also ensured by not revealing their names or any personal 
information. Only details relevant to the study were included.

\section{Results}

The results were divided into two parts: the participants' demographics, quantitative analysis of the SILL, and qualitative analysis of the open-ended questions. Below was the analysis for each part.

\subsection{Participants' Demographics}

The participants of the study consisted of 33 female EFL college students. Their average age was 21.94 and average length of English learning was 11.73 years. The majority of them reported to pass the General English Proficiency Test (GEPT) elementary level while less than $10 \%$ of them passed the GEPT intermediate level. Besides their personal information, three questions regarding English learning were shown and analyzed in Table 1. Questions 1 to 3 were adapted from the background questionnaire developed by Oxford (1990, P.282). As displayed in Table 1, the participants thought their overall English proficiency as compared with that of other students in their class was 'fair' (mean=2.0) on the scale (excellent $=4$; good $=3$; fair $=2$; poor $=1$ ). However, when comparing their overall proficiency in English with native English speakers, they thought their English proficiency was close to 'poor' (mean=1.24). The participants' perceptions of the importance in learning English were close to 'very important' (mean=2.82) on the scale (very important $=3$; important $=2$; not so important $=1$ ). Generally speaking, the participants do not possesses higher levels of self-confidence in their English ability; they all agree on the importance of English learning.

Table 1. The Participants' Demographics

\begin{tabular}{lrrrrr}
\multicolumn{5}{c}{ Descriptive Analysis } \\
\hline \multicolumn{7}{c}{$\mathrm{n}$} & \multicolumn{1}{c}{ Min. } & \multicolumn{1}{c}{ Max. } & \multicolumn{1}{c}{ Mean } & \multicolumn{1}{c}{ SD } \\
\hline Age & 33 & 21 & 25 & 21.94 & .966 \\
Years of English learning & 33 & 8 & 17 & 11.73 & 2.528 \\
Q1 & 33 & 1 & 3 & 2.00 & .707 \\
Q2 & 33 & 1 & 2 & 1.24 & .435 \\
Q3 & 33 & 2 & 3 & 2.82 & .392 \\
\hline
\end{tabular}

Note. $\mathrm{SD}=$ standard deviation; Q1=How do you rate your overall proficiency in English as compared with the proficiency of the other students in your class?; Q2=How do you rate your overall proficiency in English as compared with the proficiency of native speakers of English?; Q3=How important is it for you to become proficient in English?

\subsection{Quantitative Analysis of the SILL}

In this part, the participants' overall and individual part of language learning strategies were unfolded through descriptive (mean and SD) and referential statistics (paired-samples t-tests). First, Table 2 shows that the participants apply the strategies to their learning at a medium level (mean=3.09) based on the score interpretation proposed by Oxford (1990) and shown in Table 3. Among the six types of the strategies, specifically speaking, the most frequently-used one is compensation strategies (mean $=3.43, \mathrm{SD}=.60$ ), followed by affective strategies (mean=3.34, $\mathrm{SD}=.79$ ) and metacognitive strategies (mean=3.32, $\mathrm{SD}=.58$ ). However, memory strategies (mean=3.05, $\mathrm{SD}=.58)$ are the least frequently-used by all the participants.

Table 2. Descriptive Analysis of the SILL

\begin{tabular}{lrrrrrr}
\multicolumn{8}{c}{ Descriptive Analysis } \\
\hline \multicolumn{1}{c}{ Strategy } & $\mathrm{n}$ & \multicolumn{1}{c}{ Min } & \multicolumn{1}{c}{ Max } & Mean & SD & Rank \\
\hline PARTA & 33 & 1.89 & 4.22 & 3.05 & .58 & 6 \\
PARTB & 33 & 2.07 & 5.71 & 3.22 & .79 & 5 \\
PARTC & 33 & 2.17 & 4.50 & 3.43 & .60 & 1 \\
SPARTD & 33 & 1.78 & 4.78 & 3.32 & .58 & 3 \\
SPARTE & 33 & 2.00 & 5.00 & 3.34 & .79 & 2 \\
SPARTF & 33 & 1.83 & 4.67 & 3.24 & .83 & 4 \\
total & 33 & 2.30 & 4.32 & 3.23 & .59 & \\
\hline
\end{tabular}

Note. $\mathrm{SD}=$ standard deviation; Part $\mathrm{A}=$ memory strategies; Part $\mathrm{B}=$ cognitive strategies; Part $\mathrm{C}=$ compensation strategies; Part $\mathrm{D}=$ metacognitive strategies; Part $\mathrm{E}=$ affective strategies; Part $\mathrm{F}=$ social strategies 
Table 3. Scale for Interpretation of Scores for the SILL (Adapted from Oxford, 1990, P.300)

\begin{tabular}{lll}
\hline Frequency & Strategy Application & Scores \\
\hline High & Always or almost always used & 4.5 to 5.0 \\
& Generally used & 3.5 to 44 \\
Medium & Sometimes used & 2.5 to 3.4 \\
Low & Generally not used & 1.5 to 2.4 \\
& Never or almost never used & 1.0 to 1.4 \\
\hline
\end{tabular}

In addition to the descriptive analysis, the differences of the SILL before and after the English journal activity are also revealed in Table 4. Table 4 shows that among the six categories of language learning strategies, only two of them after the activity are significantly higher than those before the activity. They are memory strategies $(\mathrm{t}(33)=2.73$, $p=.010<.05)$ and affective strategies $(\mathrm{t}(33)=2.22, p=034<.05)$. Interestingly, the mean scores for social strategies slightly decrease after the activity.

Table 4. Paired Samples t-test of the SILL

Paired Samples t-test

\begin{tabular}{|c|c|c|c|c|c|c|c|c|c|}
\hline & & \multicolumn{5}{|c|}{ Paired Differences } & \multirow[b]{3}{*}{$\mathrm{t}$} & \multirow[b]{3}{*}{ df. } & \multirow{3}{*}{$\begin{array}{c}\text { Sig. } \\
\text { (2-tiled) }\end{array}$} \\
\hline & & \multirow[b]{2}{*}{ Mean } & \multirow[b]{2}{*}{ SD } & \multirow{2}{*}{$\begin{array}{l}\text { Std. Error } \\
\text { Mean }\end{array}$} & \multicolumn{2}{|c|}{$\begin{array}{l}95 \% \text { Confidence } \\
\text { Internal of the } \\
\text { Difference }\end{array}$} & & & \\
\hline & & & & & Lower & Upper & & & \\
\hline Pair 1 & Part A & .25 & .53 & .09 & .06 & .44 & 2.73 & 32 & .010 \\
\hline Pair 2 & Part B & .10 & .62 & .11 & -.12 & .31 & .89 & 32 & .382 \\
\hline Pair 3 & Part C & .11 & .47 & .08 & -.06 & .28 & 1.36 & 32 & .185 \\
\hline Pair 4 & Part D & .09 & .52 & .09 & -.10 & .27 & .97 & 32 & .341 \\
\hline Pair 5 & Part E & .23 & .62 & .11 & .020 & .46 & 2.22 & 32 & .034 \\
\hline Pair 6 & Part F & -.12 & .70 & .12 & -.36 & .13 & -.96 & 32 & .344 \\
\hline Pair 7 & total & .03 & .39 & .07 & -.11 & .17 & .48 & 32 & .633 \\
\hline
\end{tabular}

Note. Part $\mathrm{A}=$ memory strategies; Part $\mathrm{B}=$ cognitive strategies; Part $\mathrm{C}=$ compensation strategies; $\mathrm{Part} \mathrm{D}=$ metacognitive strategies; Part $\mathrm{E}=$ affective strategies; Part $\mathrm{F}=$ social strategies

\subsection{Qualitative Analysis}

Besides the quantitative analysis, content of the open-ended questions and post-interview were included and analyzed in the study. The participants, after a semester's long English journal writing activity, were asked to report their feelings about the activity. The participants could report their feelings in either Chinese or English. The researcher would translate the Chinese content into an English one and it would also be back-translated by an expert who had at least five years of English teaching experiences. The qualitative analysis was in accordance with the analytical process suggested by Dornyei (2007, P.246), which were (a) transcribing data, (b) pre-coding, (c) growing ideas, and (d) interpreting the data and drawing conclusions. Based on the abovementioned process, the findings are categorized into three major parts as follows. Firstly, the learners thought that writing the English journal is good for their English performance, especially for vocabulary, sentence structures, and grammar. Secondly, the learners reported to be more autonomous in learning English. They would consult a dictionary or a grammar book in order to write their English journals. Thirdly, they would have a chance to re-examine their English performance. Through this activity, they realized they should study harder to improve their English. From the perspectives of language learning strategies, the qualitative results are also in line with the two parts of strategies, which are memory, and metacognitive strategies. In other words, the English journal writing activity helped the learners enhance their application of memory and metacognitive strategies. Following are the extracts from the open-ended questions reported by the learners.

Student A

I think writing the weekly English learning journal is helpful. I can learn some new vocabulary in order to work on this activity. 
Student B

I think the weekly learning journal can help my English better. It can let me practice (English) every week even (though) I'm very busy and lazy. I always try to write English and think how I should write what I want to say.

Student C

I can try to write down what I wanna say. When I don't know the vocabulary, I can check on the dictionary. I can learn more. So, it's good!

In sum, based on the abovementioned results, the most frequently-used language learning strategy is the compensation strategy while the least frequently-used strategy, the memory strategy. After the journal writing activity, the learners' mean scores of memory strategies and affective strategies are significantly higher.

\section{Conclusions and Implications}

The results of the present study show that journal-keeping is beneficial to EFL learners' language strategy application. The participants reported to use more memory and affective strategies to their English learning. Journal writing activities are a means to raise learners' awareness of their own learning process and a way to release their tense in learning. The learners, moreover, could possibly re-examine their learning in order to better it. Therefore, besides language knowledge, strategy knowledge is also a crucial factor in language development. Strategy knowledge, claimed by many researchers, should be incorporated into teaching curricula and be delivered to learners. Through journal writing, a process of self-discovery, we may conclude that learners would become more autonomous and independent learners who are more able to search for effective ways to master a target language.

The findings of this study at least serve two pedagogical implications for the journal writing activity into an EFL curriculum. First, from the perspectives of language learners, the journal writing activity could help learners reflect more on their learning and enhance their application of language learning strategies. Second, form the view of language teachers, the study presents an alternative way to raise learners' awareness of language learning strategies and to make learners become more autonomous in learning. The journal writing, therefore, works well for both language teachers and learners.

\section{References}

Bremner, S. (1999). Language learning strategies and language proficiency: Investigating the relationship in Hong Kong. Canadian Modern Language Review, 55(4), 490-514. https://doi.org/10.3138/cmlr.55.4.490

Cohen, A. D. (1990). Language learning: Insights for learners, teachers, and researchers. New York: Newbury House Publishers.

Cohen, A. D. (1998). Strategies in learning and using a second language. London: Pearson Education Limited.

Dornyei, Z. (2007). Research methods in applied linguist: Quantitative, qualitative, and mixed methodologies. Oxford: OUP.

Ellis, R. (1985). Understanding second language acquisition. Oxford: Oxford University Press.

Gardner, R. C., \& MacIntyre, P. D. (1993). A student's contribution to second language learning: Part II, affective factors. Language Teaching, 26, 1-11. https://doi.org/10.1017/S0261444800000045

Green, J., \& Oxford, R. L. (1995). A closer look at learning strategies, L2 proficiency, and gender. TESOL Quarterly, 29(261-297). https://doi.org/10.2307/3587625

Lai, Y.-C. (2009). Language learning strategy use and English proficiency of university freshmen in Taiwan. TESOL Quarterly, 43(2), 255-280. https://doi.org/10.1002/j.1545-7249.2009.tb00167.x

Norton, B., \& Toohey, K. (2001). Changing perspectives on good language learners. TESOL Quarterly, 35(2), 307-322. https://doi.org/10.2307/3587650

Oxford, R. L. (1990). Language learning strategies: What every teacher should know. Boston, Mass: Heinle \& Heinle Publishers.

Shih, Y.-C., Chern, C.-L., \& Reynolds, B. L. (2018). Bringing extensive reading and reading strategies into the Taiwanese junior college classroom. Reading in a Foreign Language, 30(1), 130-151.

Tarone, E., \& Yule, G. (1989). Focus on the language learner. Oxford: Oxford University Press. 
Vann, R., \& Abraham, R. (1990). Strategies of unsuccessful language learners. TESOL Quarterly, 24, 177-198. https://doi.org/10.2307/3586898

Yilmaz, C. (2010). The relationship between language learning strategies, gender, proficiency and self-efficacy beliefs: A study of ELT learners in Turkey. Procedia Social and Behavioral Sciences, 2, 682-687. https://doi.org/10.1016/j.sbspro.2010.03.084

Zhang, L. J. (2010). A dynamic metacognitive systems account of Chinese university students' knowledge about EFL reading. TESOL Quarterly, 44(2), 320-353. https://doi.org/10.5054/tq.2010.223352 